\title{
Violence and the politics of memory in a global context: An overture
}

\author{
Marije Hristova $^{1}$, Lee Douglas ${ }^{2}$, Zoé de Kerangat ${ }^{3}$ and Francisco Ferrándiz ${ }^{4}$ \\ ${ }^{1}$ Faculty of Arts and Social Sciences, Maastricht University, P.O. Box 616, 6200 MD Maastricht, The Netherlands \\ ${ }^{2}$ Department of Anthropology, New York University, 25 Waverly Place, $1^{\text {st }}$ Floor, New York, NY 10003 USA \\ ${ }^{3}$ Instituto de Lengua, Literatura y Antropología, Centro de Ciencias Humanas y Sociales, \\ Consejo Superior de Investigaciones Científicas, c) Albasanz 26-28, 28037 Madrid, Spain \\ ${ }^{4}$ Instituto de Lengua, Literatura y Antropología, Centro de Ciencias Humanas y Sociales, \\ Consejo Superior de Investigaciones Científicas, c) Albasanz 26-28, 28037 Madrid, Spain \\ e-mail: marije.hristova@gmail.com, lee.douglas@nyu.edu,zoe.dekerangat@cchs.csic.es, paco.ferrandiz@cchs.csic.es
}

Submitted: 15 October 2014. Accepted: 31 October 2014

\begin{abstract}
Engaging with a growing body of literature regarding post-violence remembrance, this article considers how distinct disciplines approach the study of contemporary "memory cultures" and addresses the issues that arise when violent pasts are considered in a global, comparative perspective. The paper reflects on theoretical and conceptual debates that have emerged in the permanent seminar, Traces and Faces of Violence, an intellectual ILLACCHS-CSIC-based symposium dedicated to the interdisciplinary, comparative analysis of post-violence memory cultures in different social, political and historical contexts. It identifies two specific arenas of interpretation that have been particularly useful for engaging with global memory studies literature: the historical, judicial, political, social and personal discourses regarding the past and reflections on the relationship between memory and materiality. By "traveling" through a series of case studies and by identifying their points of convergence, as well as their points of tension, this "overture" suggests that we approach the temporal and spatial movement of memory, as well as its immobility, as two ends in the process of remembering. In doing so, the article illustrates how local case studies inform, shape and transform globally circulating discourses and how the emergent transnational repertoire of knowledge regarding violent pasts provides a framework for reacting to a wide variety of local struggles.
\end{abstract}

KEYWORDS: Memory studies; memory cultures; discourse; materiality; interdisciplinarity; globalization; post-violence remembrance

Citation / Cómo citar este artículo: Hristova, Marije; Douglas, Lee; de Kerangat, Zoé and Ferrándiz, Francisco (2014). "Violence and the politics of memory in a global context: An overture". Culture \& History Digital Journal, 3(2): e012. doi: http://dx.doi.org/10.3989/chdj.2014.012

RESUMEN: Violencia y políticas de la memoria en perspectiva global: Obertura.- Basándose en un cuerpo de literatura creciente sobre la gestión contemporánea de las violencias del pasado, este artículo se enfoca en los problemas asociados a la interpretación académica de las violencias del pasado en un marco interdisciplinar y comparado, dentro del marco de los "estudios de la memoria". El texto desglosa los debates teóricos y conceptuales que se expresan en el seminario permanente Rastros y rostros de la violencia, un espacio de debate abierto con sede en el ILLA-CCHSCSIC dedicado al análisis de las culturas memoriales del posconflicto en distintos contextos sociales, políticos e históricos. El artículo identifica dos áreas de reflexión que han resultado especialmente útiles para vincular estos intereses con debates más amplios en la literatura de los estudios de memoria: por un lado, el análisis de los discursos históricos, judiciales, políticos, sociales y personales sobre el pasado y, por otro, las relaciones entre memoria y materialidad. Identificando los puntos de convergencia y las tensiones de una secuencia de estudios de caso, esta "obertura" propone la necesidad de entender tanto el movimiento temporal y espacial de la memoria como su inmovilidad, como dos polos en el proceso de rememoración del pasado. Además, el artículo ilustra cómo los casos locales pueden incidir, modular y transformar los procesos globales y, al tiempo, cómo los repertorios transnacionales de gestión y conocimiento del pasado violento proporcionan nuevos marcos interpretativos para las luchas memoriales locales.

PALABRAS CLAVE: Estudios de memoria; culturas de memoria; discurso; materialidad; interdisciplinariedad; globalización; gestión memorial de las violencias del pasado

Copyright: (C) 2014 CSIC This is an open-access article distributed under the terms of the Creative Commons AttributionNon Commercial (by-nc) Spain 3.0 License. 
All this so that Marco Polo could explain or imagine explaining or be imagined explaining or succeed finally in explaining to himself that what he sought was always something lying ahead, and even if it was a matter of the past it was a past that changed gradually as he advanced on his journey, because the traveler's past changes according to the route he has followed: not the immediate past, that is, to which each day that goes by adds a day, but the more remote past. Arriving at each new city, the traveller finds again a past of his that he did not know he had: the foreignness of what you no longer are or no longer possess lies in wait for you in foreign, unpossessed places. - Italo Calvino, Invisible Cities

The interdisciplinary, comparative and transnational study of the contemporary recycling of past violences expressed every month in the seminar Faces and Traces of Violence, and hence in the articles selected for this issue of Culture and History, refers to an extensive and rapidly growing bibliography. This expansive literature, which includes different perspectives and scientific disciplines, forms part of the "explosion" of interest in memory or memories in Western society - particularly those linked to wars, crimes of State or political violence - and the emergence, consolidation, circulation and display of a myriad of "memory cultures" in the global sphere.

Cultural memory can be understood as a term that encompasses the deceptively simple processes of (re)constructing the past in the present. Yet approaches to this subject are highly diverse - and at times contradictory both across and within academic disciplines. Let us pose some examples. In contemporary sociology, social anthropology, literary criticism and cultural studies, for example, the growing interest in cultural memory has, since the end of the twentieth century, increasingly tried to make sense of memory building that takes place in different geographic locations in the context of late modernity. This modernity is a globalized one which many authors define in terms of interconnection, interdependence, collapse of time and space, deterritorialization, acceleration, vertigo, simulation or the saturation of experience (Harvey, 1989; Castells, 1996). Thus, the contemporary memory boom is often interpreted as a response to the acceleration of contemporary life, the dwindling of tradition and bewilderment in the face of potential oblivion (Jelin, 2001; Huyssen, 2002). In philosophy, diverse thinkers have positioned themselves in the slipstream of the Frankfurt School, regarding the concept of memory as a categorical imperative which asks us to remember every kind of barbarism and, in essence, the suffering of victims (Mate, 1991; Zamora, 2004). Historians, on the other hand, have often been skeptical towards memory, which they consider a poor counselor in the search for objective knowledge of the past (Juliá, 2011). Other perspectives, including political theory, have seen in social memory considerable potential for the fraudulent or abusive use of the past (Todorov, 2000) and have pointed to the inherent conflictive nature of remembrance, as opposed to the virtues of forgetting.
For many authors, the current boom in memory studies began with Maurice Halbwachs' influential work and his definition of the concept of "collective memory" in the 1920s (2004). A second wave of academic interest was embodied on one hand by historian Pierre Nora and his conceptualization of lieux de mémoire (1989) and, on the other, the distinction between communicative memory and cultural memory proposed by Jan Assmann (1992). Very generally, this is the backdrop against which, today, the field of memory studies has consolidated its position, bolstered by an international academic network, which boasts numerous research projects and conferences devoted exclusively to questions of cultural memory, a long list of published series produced by leading academic publishers - including Studies in Memory and Narrative (Routledge, since 1998), Cultural Memory in the Present (Stanford University Press, since 1998), Media and Cultural Memory (De Gruyter, since 2004) and Memory Studies (Palgrave McMillan, since 2009) - and academic journals like History and Memory (since 1989) and Memory Studies (since 2008).

Memory studies is an expanding field covering a variety of areas and increasingly relating to very different academic disciplines. Different authors who have tackled a wide range of objects of study position these within their own fields. Examples include monuments, memorials and museums (Gensburger, 2008; Linenthal, 1995), the representation of the past in cultural industries and their repercussions in the media (Zelizer, 1998; Kaes, 1990; Baer, 2001; Hoskins, 2009; Erll and Rigney, 2009) or celebrations, anniversaries and commemorative rituals (Gillis, 1994; Winter, 1998; Jelin, 2002). All of this research identifies memory studies as a multifaceted field requiring a trans-disciplinary approach.

In the specially bewildering area of memory studies that examines the recycling of past violences, as the first chapter in this dossier attests, the experience and representation of the Holocaust has become a key benchmark, particularly in German and US academic circles. More specifically, it has expressed the problems and limitations of historiography when tackling a traumatic past. In this area, theories of trauma, witnessing and transmission and reflections on the red lines in the politics of representation have all flourished (LaCapra, 2001; Caruth, 1996; Alexander, 2004; Mate, 2003; Agamben, 2000; Felman and Laub, 1992). Overall, the theoretical concepts elaborated in this context, not without its critics, have necessarily influenced the study of other traumatic pasts related to twentieth-century mass violence. The vast academic production and the scope of the debates in this area of memory and violence - astutely labeled as a tense past in a volume edited by Antze and Lambeck (eds., 1996) - go beyond the scope of this introduction.

In the last decades, globalization processes, as described in an even more extensive bibliography (see, for instance, Appadurai, 1990 and 1996; Featherstone, ed., 1990; Hannerz, 1996; Beck, 1999), have had a major impact on the spaces, iconographies, and circuits and the communities of memory themselves that now accumulate 
in more contemporary bodies of literature. In her book Memory in Culture (2011a), Astrid Erll reviews the field of "cultural memory studies" and refers to the proliferation of transnational memory sites, such as those connected with the attacks of September $11^{\text {th }}$, thereby emphasizing that cultural memory is gradually breaching local boundaries and the limits of the nation-state and is becoming a global phenomenon. Indeed, the most relevant recent studies of memory indicate a change in direction towards an exploration of their transnational or transcultural dimensions, emphasizing an increasing flow, interconnection and interdependence between them (Rothberg, 2009; Assmann and Conrad, 2010; Levy and Snzaider, 2010; Silverman, 2013; and this volume). The movement of people, the global influence of political stakeholders and NGOs and above all the impact of the media and social networks have led to memorialist discourses, practices and repertoires becoming ever more interconnected. Local events can have a global impact, while transnational discourses find local expressions.

Faces and Traces of Violence has specifically sought to engage with this global projection of memory studies with a particular focus on the memories of state-sponsored violence. The seminar has hosted theoretical presentations, as well as discussions regarding case studies on different social, political and cultural contexts that often use comparative model of analysis or engage with transnational perspectives. In this way, the seminar has developed an ongoing discussion on the topic of violence and memory within a global framework. In this context, discussions on human rights, victimhood politics, the politics of representation of violent pasts, the impact of new technologies in contemporary memory and memorial practices, the different forms of memory emplotment - from technical and academic to intimate forms of remembrance - have become the seminar's trademark. As a reaction to the recent transnational turn in Memory Studies, Susannah Radstone foresees that memory research will be focusing on the "locatedness of engagements with memories on the move, rather than with their "non-location" (Radstone, 2011: 111). The contributions in this volume, presenting cases-studies from all over the globe, certainly do so.

The texts that have been selected for this dossier in Culture and History represent the diversity, interdisciplinarity and richness of the topics being discussed in the seminar, and they are all linked to the global perspective on memory cultures in different ways. One could group the essays in two parts: one mainly concerned with discourse, and a second part analyzing material remnants of the past in the present. The first part focuses on the various connections between the local and the global through the analysis of discourses about the past, may they be juridical, historical or personal. In this context, the human rights paradigm has become a necessary returning topic in several of the contributions. The second part focuses on the relationship between memory and materiality. Analyses of monuments and how their (in)visibility influence memory discourses, reflections on how different
- and sometimes conflicting - memory discourses gather in specific sites and how those discourses rely on material forms and meditations and on how individuals and collectivities emotionally rely on objects and human remains as a way of remembering are key points of inflection. In more ways than one, the seminar has examined how material evidence from the past can be transformed into a vehicle for memory discourses and how that material evidence "travels", acquires and accumulates different meanings according to the multiple interpretations that can be evoked over space and time. This concern with materiality has provided a rich arena of debate in which to consider social and cultural memory in a perspective that is both comparative and transnational, both empirical and local.

In the opening essay, sociologists Daniel Levy and Natan Sznaider, provide a comprehensive sociological approach to the contemporary Human Rights Regime that unfolds the intrinsic relation between memory and human rights through the social embeddedness of the latter (Turner). Levy and Sznaider's cosmopolitan methodology (Beck) enables them to see human rights as a mediator between universal identifications and particular identities in a global context. Tracing the social life of human rights, the authors show how their origins lie, paradoxically, in the particular traumatic experience of the Holocaust and its framing during the Nuremberg trials. For them, it is these processes of institutionalization in which particular memories of atrocities become universal that proves to be key. As we will see in several contributions in this volume, frequently, local memories face processes that lead to forms of de-contextualization, in which memories of specific events and atrocities are necessarily transformed into abstract and normative universal lessons for humanity.

The authors' mnemonic approach offers a new perspective on human rights that advocates that a realist-idealist divide be overcome. In their concluding section, Levy and Sznaider convey that the current Human Rights Regime can be understood as a mediator in ongoing instances of human rights abuses. While the universality of human rights seems to be irreconcilable with particular requirements, the authors point at instances in which human rights cultures are effectively adopted to local and particular practices. Based on the social embeddedness of human rights, the authors plead for a human rights framework based on flexible principles designed to compromise rather than an absolutist one.

Historian Javier Rodrigo connects to this debate from a more historical perspective as he analyzes and questions the main transnational European tropes used to characterize the twentieth century (mostly its first half) as a time capsule that is replete of wars, massacres, genocides and other forms of mass violence, including the forced displacement of populations. In such dominant tropes, that are quite widespread although relatively recent, mass violence is not a mere epiphenomenon of broader social and political processes, but rather the very essence of twentieth-century experience. For many historians, the last cen- 
tury has been the bloodiest period in the history of mankind, in part due to the level of destruction produced by rapidly evolving military technologies and tactics, but also due to the historical conditions that made such levels of violence, terror and destruction possible. However, for Rodrigo, master metaphors used to represent expressions of violence like massacre, genocide, politicide or even the Holocaust are often more ready-to-use, homogeneizing conceptual apriorisms than the result of long and thoughtful debates on the social, cultural and political processes that lead to such acts of violence. In this context, certain concepts used to come to terms with mass violence cease to be analytical tools and uncritically inhabit the realm of commonsense, thereby impoverishing the analysis of the important differences and historical backgrounds behind the twentieth-century's main conflicts and their aftermath.

Rodrigo critically explores the much used notion of genocide - a notion that links the exercise of violence with international law and that has provoked lively academic debate under the label of genocide studies - to explain the reasons behind the conceptual poverty of such concepts as they become increasingly decontextualized. In his view, much contemporary social research has been produced within frameworks that aim to prevent the exercise of violence in the future. This operation requires the homogeneization of violent historical processes - even those embedded in mathematical explanatory models - in order to establish procedures capable of detecting potential violent outbursts and ultimately inhibiting their repetition. In the case of genocide, the most widespread "cosmovision" amongst scholars and political actors establishes that a process of mass killing is generally led by a nation-state, in which ideological, racial, religious and national building premises are paramount. Nonetheless, on the ground, much of the violence usually understood as genocide in these stereotyped, fashionable terms reveal far more complex processes that engage diverse historical contexts, that include many social actors beyond that of the State and that utilize more fluid categories regarding definitions of victims. When context reigns over overarching categorizations, a preestablished, pathological and mechanical dynamic does not exist, nor can it be replicated from case to case in order to account for acts of genocide. For Rodrigo, local analysis is more attuned to understanding such processes than the application of supranational logics. To properly understand violent processes in twentieth-century Europe that extend beyond the explanatory power of dominant decontextualizing categories, Rodrigo advocates an analysis of the specific politics of violence.

Taking up a different geographical context, Nanci Adler examines a particular aspect of the Soviet Gulags: the complex political re-elaborations that a minority of victims produced after emerging from the terrible experience of confinement that they were forced to undergo as punishment for having remained loyal to the Communist Party, the same party which ironically and almost inconceivably imprisoned them. Adler's analysis connects directly with Rodrigo's description of the complexity of twentieth-century European violence and the important historical differences between Gulags and Nazi concentration camps. Drawing on the testimonies given by loyal prisoners and returnees in the first decade of the 2000s, Adler poses some important questions that seek to unpack and illuminate the sometimes contradictory effects of violence and terror: how is it possible for such harsh forms of repression, ruthlessly experienced on victims' own bodies, to be reinterpreted as a proof of renewed allegiance with a cruel political regime like that of Stalinism? In this context, what can we learn about the processes in which social, political and personal memory are elaborated and about victimhood politics in this extreme case of ideological internalization? To try to answer these questions about enduring loyalty in a context of severe repression, Adler proposes four kinds of explanatory paths, all of them related to issues of power and belief. In developing these paths, Adler's text suggests that Communism can be approached as a faith-based belief in which political structures have a die-hard charismatic draw on followers, lingering for decades as an "assimilated ideology" despite evidence that points to harsh forms of imprisonment and trauma.

Adler first proposes that Bolshevism be considered as a secular religion that has a well-ingrained "gravitational field of indoctrination" that can provide comprehensive meaning to its followers' life experience. She suggests that the ideas of redemption and patriotic sacrifice through suffering or through martyrdom for a just cause were effective sense-making devices, as well as survival strategies for loyalist survivors. Second, Adler postulates that the study of cognitive dissonance within a partinost ("a sense of Party") framework - that is, a stratagem for reconciling the differences between expectation and reality - must be taken seriously if we are to understand these extreme forms of enduring loyalty. The third factor that Adler discusses is that of functionalism, which she describes as another survival strategy oriented to claim the benefits of membership to the Communist Party after the Gulag. And finally, Adler encourages the study of the psychosocial mechanisms of the "traumatic bond" or of the victims' identification with the perpetrators, what is often referred to as the "Stockholm Syndrome". All in all, Adler's incursion into the contradictory crossroads between modes of victimization and Party allegiance in the context of the Gulag case study sheds new light on the diverse memory building mechanisms - or, one might say selective memory - under totalitarian regimes. Her text ends on a bleak note regarding the contemporary suppression of memories reminding forms of repression experienced during Stalin's regime.

Following these discussions regarding memory discourses and different modes of remembering, Andrea Pető analyzes the opposite: the issue of "non-remembering" in post-Holocaust Hungary. She uses this term to describe the process of forgetting as well as the process by which painful memories are substituted by less painful ones in contemporary memory discourses. She argues that this is directly related to a language problem, in 
which people who did not witness past violence or people who have no direct connection to that violence must search for a language that allows them to express the silenced pasts of "others". Petö describes this process as a type of post-memory, but an excluding one, as opposed to Marianne Hirsch's inclusive notion of post-memory that refers to the creation of a community of Holocaust survivors. In Petö's examples, those who attempt to uncover stories in order to develop this new language of remembrance are cast out of a community previously found in a web of silence and complicity.

By examining official educational memory politics, Petö sheds light on the growing divide among Hungary's population regarding how the past should be remembered, and thus between communities of remembrance. Her description of non-remembering in Hungary unpacks the complex process of pillarization that divides "us" and "others" even further, even though roles are sometimes interchangeable, as the "murderers" try to make the "victims" stories visible. When official memory politics were imposed on students, they protested about their compulsory nature, arguing that these measures had little importance to them and to Hungarians in general, therefore intensifying the already existing dichotomy between "Hungarians" and "Jews". Official memory politics in Hungary have also resulted in the creation of a controversial monument that has greatly affected dominant memory discourses. The monument broadly represents Hungary as a victim of World War II related violence, thereby ignoring the fact that many Hungarian officials collaborated with Nazi Germany. The creation of this memorial has invoked heated reactions and the development of countermemory practices. Some of these practices, however, can only be performed by those identifying as members of the Jewish community, keeping the LGBT and Roma community excluded from this memory discourse. Nevertheless, by considering the examples explored in Petö's article, one realizes that there are cases where one can go beyond oneself and search this new common language in order to develop and reach out towards an alternative, post-secular framework for memory politics.

In the introduction to his article, "Dictatorship and revolution: Socio-political reconstructions of collective memory in post-authoritarian Portugal," Manuel Loff describes how right-wing memorial discourses in France, Italy, Chile and Spain mobilize the concepts of dictatorship and revolution in order to explain the historical and political forces that provoked an authoritarian reaction. This description becomes the backdrop against which Loff outlines how democracy emerged as a consequence of both military action and social revolution in 1970s Portugal. He then turns to Portugal's 1974 military coup, led by the Armed Forces Movement, and describes how these events have transformed into memories of emancipation. However, he also identifies the democratization process as a source of ambiguity regarding the social and political production of memories related to the Colonial War and colonialism more broadly. By considering how the 1974 revolution results in "emancipated memories" of histori- cal experience within Portugal and "ambiguous" memories of violence that took place away in the colonies, Loff provides insight into the complexity of historically writing the 1974 revolution from the present. By attending to the silence regarding the dictatorship and the Colonial War that provoked the end of the Estado Novo, the author provides a complex historical re-reading of the places where history, memory and silence intersect.

Loff's text provides an important "mapping out" of how the Revolution has been remembered and discussed in different periods after its conclusion. This in turn, allows the author to also track who has been able to claim a "victim" status and how this links to Portugal's amputated Nation narrative, in which discourses on multi-culturalism, multi-racialism and assimilation are thought to correct forms of racial prejudice. Finally, Loff describes the current twenty-first century Portuguese battle for memory, which he describes as an open field where antifascist memories of Salazar's dictatorship are consolidated and forced to come into contact with the conservative, revisionist historiographic discourses. For Loff, it is this open battlefield and the struggles for signification in the present that are indicative of change in how Portuguese society remembers and rebuilds its recent past.

Mexico is another country historically affected by political violence. As in many other places, the memory work related to this violence and the process of coming to terms with the past - if it is ever achieved - are very complex. Violence in Mexico has resulted in an increasingly high number of forced disappearances. Sylvia Karl's text draws links between those who disappeared during Mexico's Dirty War in the 1960s and 1970s and those who disappeared in the twenty-first century's "war on drugs". It also tackles the public visibility of families' demands that exist in relation to disappearances and governmental responses to them. The actions performed and carried out by different family and state actors have revealed processes of de-humanization, re-humanization and re-dehumanization that exist in parallel with the unsuccessful processes of transitional justice.

In her text, Karl demonstrates how the presence of different active groups that have struggled to find those who were disappeared in the Dirty War has been a key precursor in the development and public appearance of new collectivities that have gathered around the "war on drugs." In this sense, she stresses the continuity of a particular struggle for justice. In her article, the transnational aspect of these struggles emerges alongside an understanding of how the process of demanding justice, reparation and dignity is inscribed in and through a Human Rights discourse. However, continuities exist beyond the victims struggles and experiences; they also exist through the persistence of impunity, both past and present, of those perpetrators who carried out these crimes. Karl's text offers important insight into the blurred boundaries between current and past struggles regarding Mexico's disappeared - a topic that, at this present moment, as we write this introduction, is again taking center stage in Mexico as heated debates have publicly erupted regard- 
ing the shocking and still unsolved disappearance of 43 students in the State of Guerrero. These events have sparked the discovery of many other "lost" mass graves that are directly related to the murkiness and multiplicity of forms of violence that are ingrained in the country's peripheries.

Turning to another geographic context, oral historian and hispanist Eva Léger examines the preserved ruins of the French town of Oradour-sur-Glane and their projection as a global lieu de mémoire. The author shows how this ruined village, being first and foremost a national, state-sponsored memory space, has attracted, distilled, and generated a range of other memory discourses over time. By focusing mainly on the counter memories formulated through contemporary local memory associations, she portrays a complex memoryscape, in which she explores the borderlines between local, European and global narratives, familiar and institutional narratives, and gendered narratives. In describing this specific case study on the recovered memories of Spanish Republican exiles in Oradour-sur-Glane, which are voiced through both a French and a local Spanish memory association, Léger closely analyzes the production and recuperation of a transnational memory from below. The initiatives and contradictions between the two local associations point to the importance of local memory work previously completed in the town, to forms of generational transmission and to the power of global victim-centered discourses, all of which act as building blocks in the elaboration of new memories. Carefully, Léger signals the wounds in intimate family narratives that attempt to communicate the previously ignored stories of a collective that did not fit official national forms of remembrance. Departing from these "wounded memories", Léger evaluates the affective significance of Oradour-sur-Glane as a space of continuous re-signification, even if it partly reproduces dominant national and gender paradigms.

In their article, archaeologists Laura Muñoz and historian Julián Chaves consider the material evidence unearthed in mass grave exhumations in Extremadura, Spain. Paying close attention to what this evidence reveals about Francoist repression more broadly, the authors describe how archaeological analyses can enrich our understanding of history. Muñoz and Chavés approach different kinds of material traces - predominantly, human remains and personal objects - as a form of forensic, historical and archaeological evidence regarding individual experiences with violence. However, they consider this evidence holistically, thereby integrating archaeological theory, method and analysis with observations regarding landscape, memory, material culture and historical process, in order to analyze how the material traces of specific violent acts can illuminate the existence of complex strategies that sought to socially control and repress those who lost the Spanish Civil War. The authors' contribution is important in that it demonstrates how the technical expertise embedded in the disciplines of archaeology and physical anthropology can enrich our understanding of how terror was implemented not only individually, but also collectively in an attempt to establish new modes of political socialization. It is this ability to connect the tangible remains of individual persons to the repressive acts that they suffered before, during and after their deaths, that helps produce new forms of knowledge regarding the social and political context in which these various forms of violence were experienced. Rooted in scientific practice, these conclusions illuminate how techno-scientific practice can broaden our historical understandings of violence exerted as a tool for exerting control over individuals, communities and even nations.

In his article "The archives of terror and mourning in contemporary Spain", historian Alfonso Villalta considers the social valence of documents generated during the Franco dictatorship. Carefully describing the different "types" of archival collections that contain documentary evidence related to Francoist repression, the author maps out the complex web of archival practices, policies and assemblages that characterize the contemporary organization of archival collections that are of particular relevance to twentieth-century Spanish history. By taking into account discussions regarding the management of "terror archives" in Latin America's Southern Cone, Villalta artfully inserts Spanish debates regarding accessibility into a comparative, transnational perspective in which archives are understood to be complex spaces in which history and memory overlap, rather than simple collections of historical sources.

Furthermore, by considering the accumulation of photographs, documents and objects in the domestic sphere, Villalta accentuates the importance that these un-official, private archives have in the processes by which victims' kin narrate their experiences with disappearance and loss. The author argues that these other forms of documentation are key not only for the writing of history, but also for accessing and tracking the emotional responses that have grown out of extended periods of political repression. Suggesting that these emotional responses are key to fostering a more complete understanding of historical experience, Villalta accentuates the importance of subjectivity and human emotion in the production of historical knowledge. These conclusions allow the author to reflect on the benefits of establishing public memory policies that seek to recuperate, preserve, care for and circulate intimate and personal archival collections and the role that this could have in forging new collective forms of remembrance and in reinforcing shared identities based not on silence, but rather on the enunciation of lived experiences with violence.

Bringing together empirical, ethnographic data with analyses of contemporary knowledge production, anthropologist Lee Douglas examines the aftermath of an "unsuccessful" exhumation in the town of Oropesa de Toledo in Spain. In narrating the curious story of two mass graves that had "gone missing", Douglas considers the intellectual labor exerted to produce historical knowledge in a context where municipal archives are inaccessible and family histories about the Spanish Civil War and its aftermath are marked by silence and dis-information. The text 
emphasizes the importance that techno-scientific expertise has played in situating different kinds of documentary and forensic evidence as historical "fact", while also considering the importance that other knowledge forms - particularly kin-based knowledge and archival records play in engaging techno-scientific expertise in meaningful ways.

By following the work of a young, local historian, Douglas unpacks the processes through which incomplete narratives and historical dis-information are made more coherent. Pausing on the importance of an archival document that links legal names with family nicknames, the author describes how archival evidence helps elucidate kin-based knowledge and vice versa. At the same time, the author observes how an iconic photograph of four "rapadas" becomes a canvas on which victims' kin describe their experiences with Francoist violence. Through these descriptions and analysis, Douglas illustrates the distinct ways in which the tensions between silence and enunciation - between absence and presence - manifest themselves in a town where memory is present, but severely suppressed. By concentrating on the complex ways in which evidence is transformed into knowledge, the author provides important insight into diverse forms of knowledge production implicit in the task of unearthing the past.

In her article, "When memory becomes heritage: experiences from Santiago, Chile", historian Chiara Bianchini explores the processes, material shapes, messages and consequences of heritagization in Santiago, Chile. Being aware of the exemplary function that Chile already plays in memory cultures around the world, Bianchini presents her case study as an opportunity to rethink the relationship between public memorialization, urban heritage, human rights and processes of democratization and peace building. Through the analysis of three significant and recently declared historical monuments that are related to contemporary experiences with state-sponsored violence during the Pinochet dictatorship, Bianchini critically analyzes the initiatives to preserve the "difficult memories" that continue to exist in these spaces.

The analysis put forth by Bianchini resonates with those explored in the opening essay by Levy and Sznaider, while also offering new insights regarding the relationship between contemporary human rights paradigms and processes of heritagization. As such, the author convincingly demonstrates how in each of the three cases the institutional efforts to promote memorialization end up turning monuments into Foucauldian-like heterotopias, thereby leaving these spaces open to different, contradictory readings. As such, the human rights discourse proves to be Janus-faced. On the one hand, it addresses victims' claims to memorialization, while at the same time it allows for a victim-centered discourse that erases further political contextualization and avoids addressing questions about political responsibilities for crimes. In her conclusions, the author brings us back to a broader discussion of heritagization and an evaluation of the success of these practices in the development of post-dictatorial democracies.
Memory "travels" through time and through space (Erll, 2011b), and at the same time it is "ever instantiated locally, in a specific place and at a particular time" (Radstone, 2011). The contributions in this volume show that instead of analyzing memory through binary oppositions, we must approach the temporal and spatial movement of memory, as well as its immobility, as two ends in the process of remembering. Whereas local case studies inform, shape and transform globally circulating discourses and memory tropes, the emergent transnational repertoire of knowledge regarding violent pasts provides a framework to act upon other struggles, both historical and contemporary. As such, we truly wish that the notion of similar struggles for memory and justice around the globe provide a ground for (new) transnational solidarities (Silverman, 2013).

\section{REFERENCES}

Agamben, Giorgio (2000) Lo que queda de Auschwitz. Translated by A. Gimeno. Pre-Textos, Valencia.

Alexander, Jeffrey C.; Eyerman, Ron; Giesen, Bernhard; Smelser, Neil J. and Sztompka, Piotr (editors) (2004) Cultural Trauma and Collective Identity. University of California Press, Berkeley.

Antze, Paul and Lambek, Michael (editors) (1996) Tense Past: Cultural Essays in Trauma and Memory. Routledge, London.

Appadurai, Arjun (1990) "Disjuncture and Difference in the Global Cultural Economy". Public Culture 2 (2): 1-24.

Assmann, Aleida and Sebastian Conrad (2010) Memory in a Global Age: Discourses, Practices and Trajectories. Palgrave Macmillan, Basingstoke.

Assmann, Jan (1992) Das Kulturelle Gedächtnis: Schrift, Erinnerung und Politische Identität in frühen Hochkulturen. C.H. Beck, Munich.

Baer, Alejandro (2001) "Consuming History and Memory Through Mass Media Products". European Journal of Cultural Studies, 4 (4): 491-501.

Beck, Ulrich (1999) What Is Globalization? Polity Press, Cambridge.

Caruth, Cathy (1996) Unclaimed Experience. Trauma, Narrative, and History. The John Hopkins University Press, Baltimore.

Castells, Manuel (1996) The Rise of the Network Society, The Information Age: Economy, Society and Culture, Vol. I. Blackwell, Oxford.

Erll, Astrid and Rigney, Ann (2009) Mediation, remediation and the dynamics of cultural memory. Walter de Gruyter, Berlin.

Erll, Astrid (2011a). Memory in Culture. Palgrave Macmillan, Basingstoke.

Erll, Astrid (2011b). "Travelling memory". Parallax, 17 (4): 4-18.

Featherstone, Mike (1990) Global Culture: Nationalism, Globalization and Modernity. Sage, London.

Felman, Shoshana and Laub, Dori (1992) Testimony: Crises of Witnessing in Literature, Psychoanalysis and History. Routledge, London.

Gensburger, Sarah (2008) "Lugares materiales, memoria y espacio social: El recuerdo de los campos anexos de Drancy en París". Anthropos, 218: 21-35.

Gillis, John (1994) Commemorations: The Politics of National Identity. Princeton University Press, Princeton.

Halbwachs, Maurice (2004) Los marcos sociales de la memoria. Anthropos, Barcelona.

Hannerz, Ulf (1996) Transnational Connections: Culture, People, Places. Routledge, London.

Hartman, Geoffrey (1996) The Longest Shadow. In the Aftermath of the Holocaust. Indiana University Press, Bloomington.

Harvey, David (1989) The condition of postmodernity. Cambridge, MA, Blackwell. 
Hinton, Alexander (editor) (2011) Transitional Justice: Global Mechanisms and Local Realities after Genocide and Mass Violence. Rutgers University Press, North Carolina.

Hoskins, Andrew (2009) "The mediatization of memory". In Digital Memories, edited by Garde-Hansen, Joanne, Hoskins, Andrew and Reading, Anne. Palgrave Macmillan, Basingstoke: 27-43.

Huyssen, Andreas (2002) En busca del futuro perdido: Cultura y memoria en tiempos de globalización. Fondo de Cultura Económica, Buenos Aires.

Jelin, Elizabeth (2001) Los trabajos de la memoria. Siglo XXI, Buenos Aires.

Juliá, Santos (2011) Elogio de Historia en tiempo de Memoria. Marcial Pons, Madrid.

Kaes, Anton (1990) "History and Film: Public Memory in the Age of Electronic Dissemination". History and Memory, 2 (1): 111-129.

LaCapra, Dominick (2001) Writing History, Writing Trauma. The Johns Hopkins University Press, Baltimore.

Linenthal, Edward T. (1995) Preserving Memory: The Struggle to Create America's Holocaust Museum. Viking Penguin, Nueva York.

Mate, Reyes (1991) La razón de los vencidos. Anthropos, Barcelona.
Mate, Reyes (2003) Memoria de Auschwitz: Actualidad moral y politica. Editorial Trotta, Madrid.

Nora, Pierre (1989) "Between Memory and History: Les Lieux de memoire". Representations, 26: 7-25.

Radstone, Susannah (2011) "What Place Is This? Transcultural Memory and the Locations of Memory Studies". Parallax, 17 (4): 109-123.

Rothberg, Michael (2009) Multidirectional Memory. Stanford University Press, Stanford.

Silverman, Max (2013) Palimpsestic Memory: The Holocaust and Colonialism in French and Francophone Fiction and Film. Berghahn, Oxford.

Todorov, Tzvetan (2000) Los abusos de la memoria. Paidós, Barcelona.

Winter, Jay (1998) Sites of Memory, Sites of Mourning: the Great War in European Cultural History. Cambridge University Press, Cambridge.

Zamora, José Antonio (2004) Theodor W. Adorno: Pensar contra la barbarie. Trotta, Madrid.

Zelizer, Barbie (1998) Remembering to Forget: Holocaust Memory through the Camera's Eye. University of Chicago Press, Chicago. 